\title{
Summarizing strategies and writing ability of Iranian intermediate EFL students
}

\author{
Hooshang Khoshsima, Maryam Rabani Nia \\ Faculty of Management and Humanities, Chabahar Maritime University, Iran
}

Email address:

khoshsima@cmu.ac.ir (H. Khoshsima)

To cite this article:

HooshangKhoshsima, Maryam Rabani Nia. Summarizing Strategies and Writing Ability of Iranian Intermediate EFL Students. International Journal of Language and Linguistics. Vol. 2, No. 4, 2014, pp. 263-272. doi: 10.11648/j.ij11.20140204.14

\begin{abstract}
Improving writing instruction has been the focus of educational researchers during the last three decades. Instructions in writing strategies i.e. planning, drafting, revising have showed a dramatic effect on the students' quality of writing. Moreover, the use of reading and reading strategies like summarization in writing classes has generated a great deal of debate. Employing the overlap of reading and writing strategies as a framework, the present study was conducted to investigate the possible relationship between explicit teaching of summarizing strategies and writing achievement. The study used a Quasi-experimental design. Two groups of intermediate efl students were assigned to experimental and control group. According to Nelson Proficiency test results, both groups were nearly at the same proficiency level. The experimental group, in addition to writing instruction, was taught summarizing strategies explicitly through CALLA. The control group only received the writing instruction in traditional way. The result of writing pre and posttest showed the positive effect of summarizing instruction on students' writing ability. Comparing the mean score of experimental group on writing posttest $(M=14.6)$ with the mean score of control group on writing post-test $(M=12.8)$ revealed that groups have significant difference $(\mathrm{P}=.000<.05)$ and the experimental group outperformed the control group in writing posttest. Therefore, it was concluded that explicit summarizing strategy instruction could be used effectively for Iranian language teaching and learning specially for improvement of their writing proficiency and improving the strategy use.
\end{abstract}

Keywords: Summarizing, Explicit Strategy Training, Writing Instruction, Summarizing Strategies

\section{Introduction}

Today writing is a central practice in the process of teaching and learning in schools, and is often used for assessing what and how much students know about a given topic. However, learning writing seems to be the most difficult skill in language learning specially for EFL learners. As experience shows, teaching methods for writing in Iranian educational contexts are mostly productoriented and Iranian EFL students have limited knowledge about process of writing. Yet it is expected that EFL students' writings should be well organized, coherent, and involve various criteria such as using correct grammar, spelling, punctuation, capitalization, structure and be successful in communicating ideas. However, most of students have problems in writing to that extent. The difficulties of struggling writers are mostly strategic problems because most of them are not aware of appropriate strategies needed for writing. As Hadley(2003) argued, good writers show some evidence of planning or organizing before they sit down to write the first draft. Then they rescan their writing to maintain a sense of the whole composition (p.320). To do this, using cognitive and meta-cognitive strategies are demanded. But poor writers are not very thoughtful and usually have no plan when writing. In order to help the students to improve their writing, numerous methods and approaches have been designed and experienced.

In the mid-1970s, the focus of writing instruction shifted from the product approach to process approach. As its name suggest, this approach concentrate on the creation and process of writing a text as a product. Moreover, by changing the focus of applied linguistics in the mid-1970 from the emphasis on teaching and teacher-centered classrooms to learning process and learner-centered classrooms, learner were supposed to have more responsibility in creating their learning. As a result, teachers were regarded mostly as learner trainer than an instructor and process-writing approach combined a number of writing instructional 
activities and extended writing practice opportunities to make learner independent and more responsible for their learning. White and Arndt (1991) introduced writing as a complex, cognitive process that needs to continuation of intellectual effort over a considerable period. As the concept of writing has changed from that of a product to a process, the emphasize of the teachers also changed to provide more assistance during the prewriting, writing and post writing phases of assigned writing activities. Chastain (1988) asserts that "Newer approaches contend that students learn to write by writing" (p.264).

Instruction in writing demands more practice and students should be encouraged to analyze and evaluate them in order to have an effective and coherent writing. Among the instructions and elements that introduced as an effective tool in improving the writing, writing strategy instruction has shown a dramatic effect on students writing. Strategy training is defined as teaching the use of strategies in order to improve learners' effectiveness. The use of readings in writing classes has also generated a great deal of debate among those searching for methodologies that increase improvement in writing proficiency. Thus, teaching strategies of how to gain the gist of a text as a reading strategy is a good help for writing about the topic of that text. Within a wider framework of reading strategies, derivative researches on the strategies used for summarizing information by EFL/ESL or non-native speakers of English has attracted the interest of some researchers in Applied linguistics as it has been realized that the ESL/EFL students' ability to summarize information is an important skill required for directing learning successfully at college and university level. Summarizing is a process demanding higher thinking for synthesizing the content and identifying important information and main idea of a text. By using this strategy or skill, students can understand better what they are reading and how to write by first writing the key information, then supporting the main idea. In addition, writing a summary help learners to retain information deeply. A number of researchers introduced summarizing as a writing strategy to recover the previous knowledge e.g. Wenden (1991), Knudson (1998).It incorporates both reading strategies such as Inferencing and writing strategies such as drafting \& planning in making outlines. Summarizing as an important skill involves the strategies and rules proposed by some researchers and according to Reidle (2011) it is "an evaluative tool that allows students to self-evaluate what they know and what they do not know" (p.2).

A number of universities of different countries consider summarization as a skill which should be taught. Teachers should provide text for students to summarize and pay much attention to the rules and strategies needed for this skill and do not assume that most of the students have mastered this skill previously or know the rules completely. Teachers must be persuaded to accept summarization as a crucial skill that their students should practice as often as possible as a part of an integrated reading and writing program. It is speculated that EFL learners need an explicit instruction on global summarizing strategies to become proficient writers and readers. Strategic learning and strategy-based instruction (SBI) have been proved to be an effective approach in leading learners to better learning, thus, teaching summarizing strategies might be effective in learning skills. Various studies found that to be an effective learner it is better to become strategic learner. According to Chamot (2004), "Strategic learners have metacognitive knowledge about their own thinking and learning approaches, a good understanding of what a task entails, and the ability to orchestrate the strategies that best meet both the task demands and their own learning strengths."(P.14). These learners are identified as "good language learners" and are successful in their learning. Early researches went toward just identifying and classifying learning strategies with recognizing strategies used by effective and good language learners through interview and thinking -aloud procedure and so on. It was not long before language educators realized that simply recognizing learners' contributions to the process of learning and identifying strategies was not sufficient. As Freeman (2003) pointed out that:

In order to maximize their potential and contribute to their autonomy, language learners- and specially those not among the group of so-called 'good' learners needed training in learning strategies.(p.159).

It seems clear that the issue of successful learning and strategic learning are concerned in learners' autonomy and independent language learning since the strategies play a key role in this regard. As Kumaravadivelu (2006) points out, learners by using appropriate learning strategies can monitor their learning success and maximize their learning potentials. Thus, to enhance learner autonomy and independence that make learners to take charge of their own learning the focus of trainers should change from learning students what to learn to learn them how to learn. Research on learning to learn approaches for learner autonomy has produced useful taxonomies of learning strategies (e.g. O'mally and Chamot, 1999, Oxford, 1990). These strategies involve cognitive, metacognitive, social and affective strategies for achieving the goal. Cognitive strategies according to Richard and Schmidt (2002) incorporate any mental process that learner make use of in language learning such as Inferencing, Generalization, Deductive learning, Monitoring and Memorizing. Proponents of this approach make learners aware of learning strategies and train them to use those effectively in all settings especially in academic situations. On the other hand, Meta cognitive strategies control the learning process and take the necessary actions and steps in solving the problem e.g. planning, monitoring and evaluation.

As it was noted, writing is a complex and important skill demanding more practice by EFL learners. Despite its importance, many students are struggling to master this skill. Thus, finding a way for improving writing is necessary especially for EFL students. Furthermore, it was 
noted, SBI in writing has been shown a dramatic effect on writing proficiency. Moreover, according to one research conducted by Graham and Perin (2007) after writing strategy instruction, summarization instruction has shown agreat effect in improving writing. The purpose of this study is to focus on the kinds of summarizing strategies (cognitive and meta-cognitive) adopted from Chimbganda (2006) and Idris, Baba \& Abdulla (2008, 2009) which are used by students in summarizing a text with complex ideas and in addition incorporate them into writing instruction of classes in an integrated manner. Briefly, the main purpose of this study is to study the effect of explicit teaching of the summarizing strategies in writing ability of EFL students in order to offer selective strategies for solving the problems of students in writing especially when writing summaries. Another goal of this study is to provide extended practice with expository writing and revision, and integrating these strategies into teachers' instruction in order to encourage students to take responsibility for their own writing.

\subsection{Research Hypotheses}

The following hypothesis is to be tested at the end of the present research:

1- The explicit summarizing strategy training has no effect on writing performance of Iranian intermediate EFL students.

\section{Review of the Related Literature}

\subsection{Theoretical Framework}

The theoretical framework of this study is based on the cognitive approach for learning. It began in the early 1970s, when language learners were seen to be active and more responsible for their own learning and writing instruction changed from the product approach to process approach. This cognitive approach itself was provided by cognitive psychology that according to Richard \& Schmidt (2002) is a branch of psychology that deals with such processes as attention, perception, comprehension, memory, and learning. In contrast with behaviorism, cognitive psychology is concerned with mental processes and the representation of knowledge in the mind. Studies and researches in learning theory have supported the Cognitive Academic Language Learning Approach (CALLA) like Chamotet al (1992). This approach was recognized as a path that views learners as active participants who are mentally involved in the process of teaching and learning and suggest ways for teachers to activate the mind of students by asking them to reflect on their language learning and develop a strategic approach for learning and problem solving. Following cognitive approach, Rubin (1975) identified some of learning strategies as he studied good language learners and what they did to be successful learners. It was hypothesized that some of the success of successful learner may be the result of using more beneficial LLS. According to Rubin (1975 as cited in
Larsen-Freeman , 2003), good language learners are willing and accurate guessers who have a strong desire to communicate, they attend to both the meaning and the form of their message and practice and monitor their speech as well as the speech of others.

\subsection{Strategy Training and Process Writing Instruction}

Numerous studies have concentrated on the positive effect of explicit strategy training on writing performance. As it was mentioned when strategy training is incorporated in language curriculum, teachers have to teach students how to learn in addition to teach them what to learn. It can help students get familiar with their own learning styles and learning process and continue to learn after they have completed formal study of the language. It encourages students to adopt strategies that are good for efficient learning and becoming autonomous.

Various writing instruction models have been developed by researchers which most of them are strategy oriented to provide students with different strategies that they need and implied to strategy training as an important component of writing instruction. According to Leavitt-Noble (2008 as cited in Akincilar\&Vildan 2010), integrated model for teaching writing that integrate explicit teaching, modeling, strategy instruction and external dialogue and using rubrics is more effective and successful way for teaching writing. Recent researches by Graham et al (2006), Mcmullen (2009), and Akincilar (2010), proved and pointed out the effect of strategy training on writing improvement. Graham \&Perin (2007) in a study thought the strategies for planning, revising, and editing in writing composition to adolescents in order to teach the students to use these strategies independently. Their results supported strategy instruction effects especially for lower level students. They also proposed SRSD as a particular and effective approach for teaching writing strategies. Akincilar (2010) in another study, investigated the effect of PLEASE strategy training through SRSD on overall length and quality of writing which according to the results gained, there was improvement in length and overall quality of writing in addition to an increase in students' self-confidence.

Effects of strategy instruction in writing have been documented on all writing strategies (cognitive and metacognitive). Graham and Harris (2005) introduced all the effective strategies for writing better. The scientifically validated writing strategies according to them are Selfmonitoring and recording writing output, PLASE, PLANS, STOP and LIST, Summary writing, Set goal for revising, Peer revising, CDO, Self-monitoring and recording story parts, Vocabulary, Story grammar, Set general and elaborated goals, Three-step strategy with TREE, STOP and DAR, SCAN, POWER strategy Explanations, POWER strategy Comparison/contrast and Report writing. One of the proposed strategies is summary writing that as a complex skill incorporating reading and writing activities consists of cognitive and meta-cognitive strategies for scanning and skimming, inferencing to find important 
points, deleting unnecessary information, generalizing and combining sentences having key ideas, constructing information in their own word and self-assessment.

\subsection{Summarizing Strategies and Writing Achievement}

Summarizing is a skill that enhances students' writing and comprehension because it requires reprocessing information in a written text or heard in a listening task and requires expressing that information in their own words to reconstruct the meaning in a condensed form. As it was noted, this skill need the attention and learning beneficial strategies concerned with both reading and writing. Chimbganda (2006) detected the overall strategies used by ESL students when summarizing which involve Information processing Strategies (Understanding by directed attention, scanning \& skimming, noting, meaning, marginal and inappropriate strategies), Summary production Strategies (planning, recasting/paraphrasing, reproduction strategies) and Self-assessment Strategies (directed attention, verification, correction and evaluation strategies. He used questionnaires, taped interviews and summaries for collecting the data.

Idris et al $(2008,2009)$ by conducting an effective study were also focused on the importance of summarization skill that according to them "involves multiple cognitive activities such as reading and understanding of text, identifying relevant theme, and generating a shorter version of it" (P. 200). They designed an algorithm by detecting the summarizing strategies used by expert students through computer-based summarization assessment system in Malaysia. From the analysis, they identified eight summarizing strategies and their rules which are then transformed into a set of heuristic rules on how to determine the summarizing strategies. The strategies involved Deletion, Sentence combination, Topic sentence selection, Syntactic transformation, Paraphrasing, Generalization, Sentence reordering, and Invention. They developed an algorithm based on the heuristic rules proposed by Brown and Day (1983) and performed some experiments to evaluate and support the prescribed technique. It was assumed that most students have little knowledge about summarizing strategies or they might not know the importance of using these strategies. Thus, in order to tackle the students' difficulties in summarizing Chimbganda (ibid) suggested that pre-reading strategies and summarizing strategies should be taught. By spreading the studies related to summarizing strategies instruction and revealing its effect on reading comprehension and summary writing, the fact that there is an overlap between reading and writing strategies for developing a summary suggested teaching summarizing strategies may be effective in writing, too.

Literature provide report on the effect of summarization instruction on writing ability. This instruction as stated by Graham \& Perin (2007: 449)“involves explicitly and systematically teaching students how to summarize texts. This can include teaching strategies for summarizing text or instructional activities designed to improve students' text summarization skills". In the view of Graham \&Perin (2007), as a teacher guides students through various writing strategies; like summarizing strategies, he/she assists them in preparing academic writing assignments by using readings as a basis to practice such skills like summarizing, paraphrasing, interpreting, and synthesizing concepts.

Numerous studies were conducted to investigate the effectiveness of summarization instruction in writing. Lee (2010) used of coping and summarizing instruction to develop the writing and reading of 60 EFL Korean students. He compared the mean score of four groups of students on reading and writing as a whole. As the results showed students of summarizing group showed much enhancement in organization, structure and grammar area of writing than reading, although their reading inferencing was also increased. Knudson (1998) also reached to a positive effect of summary writing and summarizing techniques on writing ability of college-bound students. As he reports instruction in summarization was more effective for improvement to position, support, macro level skills and micro-level skills in writing than other instruction like synthesis instruction.

MousapourNegari (2011) in another related study to strategy instruction, used concept mapping strategy instruction for improving writing achievement of EFL learners. A concept map as a learning strategy represent the relationships among concepts with the visual representation of key words that students according to it can identify main issues of a text and organize these key issues in a meaningful way. The results of the Analysis of Covariance revealed the instruction of concept mapping strategy had a positive effect on EFL learners' writing achievements.

In short, the previous studies mostly agreed on the following facts:

- $\quad$ Successful learners employ useful strategies that are teachable to less skilled learners.(Rubin, 1975, Brown, 2001, Nunan, 2001)

- Developing students' knowledge about their own thinking processes is basic for developing and improving their language learning and proficiency.(Cohen, 1998, Chamot,2004)

- Strategy based instruction encourages students to adopt strategies that are good for efficient learning and develop the autonomy and independence of learners.(Wenden 1991)

- There is a positive relationship between SBI and writing achievement. (Graham et al, 2006, Mcmullen, 2009, Akincilar,2010)

- The use of summarization instruction in writing classes is not only effective in summary writing but it is also effective in writing achievement.(Knudson, 1998, Graham \& Perin,2007, Lee, 2010) .

According to these results it was found that summarization instruction is effective in writing, but as the evidence showed these studies mostly concentrated on the influence of summarization not training this skill strategies 
step by step to students. On the other hand, the studies investigating the effect of summarization were acted mostly on ESL learners and its benefit was clarified on writing components or only summary writing. Therefore, as it was proved that summarizing instruction improved the reading, components of writing, \& summary writing of ESL students, it seems the effect of summarizing strategies instruction should be considered on overall writing quality of writing and for EFL students, too. Mainly because EFL students have much problem in writing and summary writing Thus, the researcher decided to investigate the effect of teaching these strategies on overall writing ability of Iranian Intermediate EFL students.

\section{Methodology}

\subsection{Participants}

Participants in the study, were 50 intermediate undergraduate students majoring Nautical in Maritime University in Chabahar, Iran. All the participating students were male and completed 12 years of schooling prior to their registration in college. They were the researcher's students that were learning general English course offered by the foreign language department of Chabahar University. They were nearly at the same language proficiency, which was determined by NELPT (1976), test 450 part C, which is claimed to be standard with regard to the portion of its reliability. By chance, the two selected classes consisted of almost students of the same language proficiency level. Twenty-five students were participating in control group as well as experimental group receiving the regular 12-week writing course. Participants were not informed about the purpose of the study, since the results of the study may be influenced positively or negatively by informing the purpose to students.

\subsection{Procedures}

During the treatment, students in experimental group in addition to learning writing and exercising how to write an essay or develop a paragraph through the Paragraph Development book (1990) and practicing process writing, practiced different summarizing strategies identified and taught based on rule-governed approach adapted from Brown and Day (1983) in different contexts. Summarizing strategies were demonstrated and modeled using the Cognitive Academic Language Learning Approach (CALLA) adapted from Chamot (2004) to help students learn how to summarize and write a summary. The model had six instructional phases: 1. Preparation phase. 2. Presentation 3. Practice the strategy with familiar tasks 4. Monitoring and evaluating their own strategy use immediately after each practice.5. Expansion, students should learn to transfer learned strategies to new tasks and combine strategies into clusters.6. Finally, assessment that teacher assesses students' use of strategies and its impact on their performance. These treatment sessions lasted nearly two months. In SBI program, students were provided with assistance in their native language when they were learning strategies. Using their native language made the teacher sure they understood the strategies. Participants also were given a self-made handout to practice these strategies independently.

According to the basic summarizing rules suggested by Brown and Day (1983), 8 types of summarizing strategies were identified by Idris et al (2008). These strategies are topic sentence selection, deletion, sentence combination, paraphrase, generalization, syntactic transformation, sentence reordering and invention. Chimbganda (2006) also detected similar strategies including cognitive strategies (Note-making, Grouping, Resourcing/ recombination, Deduction/Inferencing, Contextualization and Repetition) and Meta-cognitive Strategies (Planning, Selective/ Directed Attention, Self-monitoring/Evaluation). Some of the strategies detected by Chimbganda (ibid) were practically the same as Idris (ibid). Each session devoted to teaching at least two summarizing strategies. The structure of the sessions for teaching the strategies e.g. topic sentence selection strategies were as follow:

1.At first students were prepared by providing a description of the strategy and stating its goal and importance. Teacher told the students they were going to learn another strategy for summarizing named topic sentence selection strategy. It was defined as a strategy, which involves choosing one main sentence that represent the key idea and identifying relevant information from the original text. They were informed that this strategy help them to improve their comprehension of a reading passage and help them in writing best by planning to write a main sentence first. Then they were asked to brainstorm how they think about this strategy? How this strategy may help them to write a summary.

2.The teacher modeled the strategy by writing the main sentence of first paragraph in a text presented to students before starting the session. The teacher wrote the main sentence on the board and explained a summary sentence is produced by topic sentence selection if cue phrases e.g. "It is concluded that, She/ He discovered that, She/he claims that" and the location of these cues (normally at the first or last sentence of the paragraph in the original text) are found in the sentence. The teacher asked students whether the details presented in the next sentences supports the main idea.

3. The students were asked to use this new strategy in finding the main sentence of the next paragraph in the passage. In this phase, the teacher guided students in determining statements that support main idea by revealing sentences, which are more central to the main idea, provided scaffolding by giving appropriate feedback, and gradually shifted the responsibility to students in finding the main sentence.

4. In this phase, teacher made students to monitor their learning and evaluate whether they used topic sentence selection strategy appropriately. 
5. Students were asked to use the topic sentence selection strategy for next paragraphs and for writing a summary using other strategies they have learnt. In this stage, teacher showed the students which by putting these important sentences together and in a brief form, the main concept of the passage is better comprehended.

6. Finally the teacher collected the summaries and assessed them considering the new strategies they were taught. The feedback was given to students in the next session before practicing the new strategies. Students were assigned homework and were asked to practice using these strategies.

Following the writing instruction for the students in control group, they wrote nearly 12 writings in the class, further they were assigned to write eight writings at home. In summary, the control group's instructions were presented practicing the basic format of writing paragraphs, and feedback to support their knowledge for developing a paragraph. The ultimate goal for teaching writing to control group was to teach students use the writing strategies independently. However, these strategies had not been taught explicitly as the experimental group.

\section{Results and Discussion}

As explained above, the primary instrument for measuring the students' growth in writing was the pre-and post-test writing. For analyzing the scores Statistical Package software for Social Sciences (SPSS, version .17) was used. The results were discussed under two main categories of independent sample pre and posttest and paired sample pre and post test of written essays.

In order to explore to what extent the raters have agreed on their rating for pre-test, the Pearson Product Moment reliability test was conducted and showed these results: The correlation between raters' scores for control group and experimental group was $\mathrm{r}=.693$ and $\mathrm{r}=.709$ respectively that indicate the strong correlation between raters' scores. Before the treatment, in order to see whether the two groups were at the same level of writing proficiency, a TOEFL writing proficiency test was administered to both groups.

\subsection{Comparison of Control and Experimental Group prior to the Experiment}

Table 4.1. group statistics

\begin{tabular}{llllll}
\hline & Group2 & N & Mean & Std. Deviation & Std. Error Mean \\
\hline \multirow{2}{*}{ Pretest } & Experimental & 25 & 7.60 & 1.633 & .327 \\
& Control & 25 & 7.28 & 1.595 & .319 \\
\hline
\end{tabular}

Table 4.2. Independent T-test for both groups on Pretest:two description for table 4.1?

\begin{tabular}{|c|c|c|c|c|c|c|c|c|c|c|}
\hline & & \multicolumn{9}{|c|}{$\begin{array}{l}\text { Levene's Test } \\
\text { for Equality of t-test for Equality of Means } \\
\text { Variances }\end{array}$} \\
\hline & & \multirow[b]{2}{*}{$\mathbf{F}$} & \multirow[b]{2}{*}{ Sig. } & \multirow[b]{2}{*}{$\mathbf{T}$} & \multirow[b]{2}{*}{ Df } & \multirow[b]{2}{*}{$\begin{array}{l}\text { Sig. (2- } \\
\text { tailed) }\end{array}$} & \multirow[b]{2}{*}{$\begin{array}{l}\text { Mean } \\
\text { Difference }\end{array}$} & \multirow[b]{2}{*}{$\begin{array}{l}\text { Std. Error } \\
\text { Difference }\end{array}$} & \multicolumn{2}{|c|}{$\begin{array}{l}95 \% \text { Confidence Interval of } \\
\text { the Difference }\end{array}$} \\
\hline & & & & & & & & & Lower & Upper \\
\hline \multirow{2}{*}{ Pretest } & $\begin{array}{l}\text { Equal variances } \\
\text { assumed }\end{array}$ & .036 & .849 & .701 & 48 & .487 & .320 & .457 & -.598 & 1.238 \\
\hline & $\begin{array}{l}\text { Equal variances not } \\
\text { assumed }\end{array}$ & & & .701 & 47.973 & .487 & .320 & .457 & -.598 & 1.238 \\
\hline
\end{tabular}

The independent t-test for control and experimental group compared the mean score of the control group $(\mathrm{M}=7.28)$ and the mean score for experimental group $(\mathrm{M}=7.60)$. Considering the mean difference of the two groups (.320) and, of course, the $\mathrm{p}$ value $(\mathrm{p}=.487>.05)$ shows that the groups are nearly the same or, at most, there is not any significant difference between them.

Table 4.3. Paired Samples Statistics

\begin{tabular}{llllll}
\hline & & Mean & N & Std. Deviation & Std. Error Mean \\
\hline \multirow{2}{*}{ Pair } & Posttest & 12.80 & 25 & 2.141 & .428 \\
& Pretest & 7.28 & 25 & 1.595 & .319 \\
\hline
\end{tabular}

\subsection{Comparison of Pred Posttest on Control Group}

It was expected that control group writing scores due to the writing and practicing writing during one semester should change and progress. To see changes (if any) in the control group, a paired t-test was conducted to compare the results of pre and posttest. The results are presented in the following table (Table 4.4). 
Table 4.4 Paired Samples Test Pre and Post-test for Control Group

\begin{tabular}{|c|c|c|c|c|c|c|c|}
\hline & \multicolumn{5}{|c|}{ Paired Differences } & \multirow{3}{*}{$\mathbf{T}$} & \multirow{3}{*}{ Df Sig. (2-tailed) } \\
\hline & \multirow{2}{*}{ Mean } & \multirow{2}{*}{ Std. Deviation } & \multirow{2}{*}{ Std. Error Mean } & \multicolumn{2}{|c|}{ 95\% Confidence Interval of the Difference } & & \\
\hline & & & & Lower & Upper & & \\
\hline Pair Posttest - Pretest & 5.520 & 2.044 & 409 & 4.676 & 6.364 & 13.505 & 24.000 \\
\hline
\end{tabular}

Table (4.4) shows that the control group has made a progress during the course of writing. The mean score of this group on pretest and posttest was 7.28 and 12.80 respectively. The $\mathrm{p}$ value is smaller than $.05(\mathrm{p}=.000<$ $\mathrm{p}=.05$ ); therefore, it can be concluded that the group has made a progress compared with the outset of the study and this is for the effect of one semester teaching and practicing in writing.

\subsection{Comparing Pre and Post-Test for Experimental Group}

Considering the same paired t-test as control group in order to see changes (if any) in the experimental group, the results of writing pre- and post test of experimental group was also compared. The results are presented in the following table (4.5).

Table 4.5. Group Statistics

\begin{tabular}{llllll}
\hline & & Mean & N & Std. Deviation & Std. Error Mean \\
\hline \multirow{2}{*}{ Pair } & Posttest & 14.60 & 25 & 1.472 & .294 \\
& Pretest & 7.60 & 25 & 1.633 & .327 \\
\hline
\end{tabular}

comparison of pre- and post test for experimental group

\begin{tabular}{|c|c|c|c|c|c|c|c|c|c|}
\hline & & \multicolumn{5}{|c|}{ Paired Differences } & \multirow{3}{*}{$\mathbf{t}$} & \multirow{3}{*}{ Df } & \multirow{3}{*}{$\begin{array}{l}\text { Sig. (2- } \\
\text { tailed) }\end{array}$} \\
\hline & & \multirow{2}{*}{ Mean } & \multirow{2}{*}{ Std. Deviation } & \multirow{2}{*}{$\begin{array}{l}\text { Std. Error } \\
\text { Mean }\end{array}$} & \multicolumn{2}{|c|}{ 95\% Confidence Interval of the Difference } & & & \\
\hline & & & & & Lower & Upper & & & \\
\hline Pair & Posttest - Pretest & 7.000 & 1.354 & .271 & 6.441 & 7.559 & 25.849 & 24 & .000 \\
\hline
\end{tabular}

Table 4.5 shows the experimental group has made a considerable progress at the end of the course. Considering the results presented in the table (4.5) it can be concluded that there has been a substantial change in the experimental group. A comparison of the mean scores of this group prior to and at the end of the course yielded a t value of 7.00 and a $\mathrm{p}$ value of .000 . As it is observable, the significance level of $\mathrm{p}=.0000<\mathrm{p}=.05$ is a witness as to how the experimental group has undergone a significant progress. It suggest the summarizing strategies can increase writing learning, according to its pretest/posttest mean difference and the $p$ value $(p=.000)$.

\subsection{Comparison of Both Groups on Posttest}

In this section, we are about to see which group performed better the groups who received just conventional writing instruction or the groups who received summarizing strategies plus the writing instruction. Thus, the post-test results of control and experimental groups were compared, to answer the main question and to see whether there was any kind of change in the writing of experimental group. In order to see the efficiency of teaching summarizing strategies in writing ability of Iranian students, like the previous parts, the results, are presented through a table.

Table 4.6. Independent t-test for both groups on post-test

\begin{tabular}{|c|c|c|c|c|c|c|c|c|c|c|}
\hline & & \multicolumn{2}{|c|}{$\begin{array}{l}\text { Levene's Test for } \\
\text { Equality of Variances }\end{array}$} & \multicolumn{7}{|c|}{ t-test for Equality of Means } \\
\hline & & \multirow[b]{2}{*}{$\mathbf{F}$} & \multirow[b]{2}{*}{ Sig. } & \multirow[b]{2}{*}{$\mathbf{T}$} & \multirow[b]{2}{*}{ df } & \multirow[b]{2}{*}{$\begin{array}{l}\text { Sig. (2- } \\
\text { tailed) }\end{array}$} & \multirow[b]{2}{*}{$\begin{array}{l}\text { Mean } \\
\text { Difference }\end{array}$} & \multirow[b]{2}{*}{$\begin{array}{l}\text { Std. Error } \\
\text { Difference }\end{array}$} & \multicolumn{2}{|c|}{$\begin{array}{l}95 \% \text { Confidence Interval } \\
\text { of the Difference }\end{array}$} \\
\hline & & & & & & & & & Lower & Upper \\
\hline \multirow[b]{2}{*}{ Posttest } & Equal variances assumed & 3.731 & .059 & 3.46 & 48 & .001 & 1.800 & .520 & .755 & 2.845 \\
\hline & $\begin{array}{l}\text { Equal variances not } \\
\text { assumed }\end{array}$ & & & 3.46 & 42.546 & .001 & 1.800 & .520 & .752 & 2.848 \\
\hline
\end{tabular}


According to the statistics in Table 4.6, the mean score of the control group on the posttest is 12.80 while that of the experimental group is 14.60 . The mean difference of the two groups, as the table shows, is 1.80 and since the $p$ value is $p=.000<p=.05$, it can be concluded that the experimental group has performed significantly better than control group on the posttest.

\subsection{Discussion}

Since the instructional method for teaching writing and practicing writing was the same, the significant larger progress of the experimental writing is an honest and reliable proof for the effectiveness of summarizing strategy instruction. The higher writing scores of experimental group compared to control group's scores showed that the teaching of summarizing strategies had an effect on writing quality. In addition, although the writings were scored based on a holistic rubric, the raters reported that the success of experimental group than control group was mostly for using appropriate and sufficient explanations, examples, and details to organize and develop their writing and addressing the topic well. This can be interpreted in several ways. It showed the knowledge of students for benefits of using a number of summarizing strategies, which help them in writing well, has been increased. Or it could be for using reading in writing instruction which drew the attention of students to new vocabularies, organization and cause reflecting on the passages. The other explanation for improving the organization and supporting the main idea more in experimental group would be that the students might have given more attention to identify main idea, important and related details to restate those details in their own words. Thus, they learned how to support the main idea well. The findings for investigating the main hypothesis are consistent with the findings of, Knudson (1998), Rumero Perez, Bandera, Leon \&Cervan(2003), Graham \&Perim (2007), Lee (2010) which provided evidence for the positive effect of summarization instruction on writing ability and components of writing. The findings also support MousapourNegari (2011) results on effectiveness of strategy instruction for writing although she investigated positive effect of concept mapping strategy instruction on EFL learners' writing achievement.

In short, the writing proficiency of students in the summarizing strategy training group was improved more than those in control group. Thus, the main hypothesis of this research can be rejected by these results. It seemed that writing instruction based on teaching summarization facilitate development of writing. The lack of a significant improvement in the control group compared to experimental group indicates that simply offering students to practice writing through the conventional instruction was not sufficient to develop their writing ability.

\section{Conclusion\& Implications}

The study reveals the effect of step by step teaching of summarization on students' writing quality. Based on data presented in the previous parts, positive effect of summarizing strategy training on experimental students' writing products has been confirmed. The findings support the theoretical prediction about the effectiveness of strategy instruction and findings of earlier researches on explicitly strategy instruction on writing ability.

To conclude, it was assumed that the explicit summarizing strategy training have no effect in developing writing. Findings illustrated the great effectiveness of the conscious applying the summarizing strategies in helping students to develop their writing and led the students to the appropriate adoption of certain strategies and procedures for producing a coherent and well-organized writing. Through practicing summarizing strategies, the students become more aware of the process underlying the written text and they learn how to support the main idea when writing.Previous research on summarizing mainly discussed the advantages of summarization instruction on summary writing as a kind of writing or discussed it in relation to components of writing but possible advantages that the explicit summarizing instruction could provide in overall writing quality and frequency of using these strategies had been given less attention. In addition, as far as the literature showed, despite the importance of summarization in language learning, teaching summarizing strategies in all language skills area has been given less attention in Iranian universities and schools. Considering these results and results of other SBI studies on writing, the researcher concludes generally that SBI, especially summarization instruction is an effective tool for improving writing and increasing the knowledge of students about appropriate strategies in writing.

The pedagogical implications arising from this study mostly are related to the importance of the strategy-based instruction in writing in general and the importance of teaching summarizing strategies in particular. In conventional teacher-centered writing classrooms, mostly writing is regarded only as a product. The teacher teaches the students by only explaining about the structure and formats of writing. The students are also expected to write according to the rules they are learning through the books and teachers. As it is suggested by researchers the writing instruction should incorporate both process and product approach in teaching writing, in other words the process approach should be used as a tool for gaining the best product. Furthermore, if learners become aware of the underlying process in their own learning and know how to apply good strategies for the task consciously, they become more involved and responsible for their learning. Thus, teachers should increase the students' confidence in using the appropriate strategies by explicit teaching them and scaffolding to use them more in order to become independent and autonomous learners. The syllabus designer also should consider incorporating these strategies in writing books as well as reading books.

With regard to the effects of strategy instruction, which 
consider the good language learner strategies as a base for teaching strategies, the current study focused on the strong relation between reading and writing through summarizing strategies that has been to a degree neglected in Iranian universities and schools. There was used a quasiexperimental design to carry out this study, thus, there is limitation in the generalizability of results to other context. It is suggested for further research to consider a trueexperimental design.

On the other hand, this study used the summarizing strategies determined by ESL researchers. Another similar study should be conducted to investigate the summarizing strategies adopted by Iranian university students and high school students. To detect these crucial strategies in Iran, personal interviews with individual students following questionnaires and think aloud procedure should be conducted to establish exactly the strategies they used and prefer when producing a summary. Examining the summarizing strategies used by female and male students in different proficiency level is also suggested to investigate separately.

\section{References}

[1] Akincilar, Vildan. (2010). The Effect of " PLEASE" Strategy Training Trough the Self-regulated Strategy Development(SRSD) Model on Fifth Grade Students' Decriptive Writing: Strategy Training On Planning. Dissertation and Thesis database, 1-259.

[2] Arnaudet, M.L \& Barrett, M.E. (1990). Paragraph Development: A guide for students of English. Washington, D.C.: By Prentice Hall Regents, Prentice-hall, Inc.

[3] Brown, H. D. (2000). Principles of language learning and teaching. New York: Pearson Education.

[4] Brown,A.L \& Day,J.D. (1983). Macrorules for Summarizing Texts: the developmet of Expertice. Urbana-Champaign: center for the study of Reading.

[5] Celce-Murcia, M. (2001). Teaching English as a second or Foreign Language. United States: Heinle \& Heinle.

[6] Chamot, A. (1995). Implementig the Cognitive Academic Language Approach CALLA in Arlington, Virginia. The Bilingual Research Journal, Vol. 19, No.3 , 379-394.

[7] Chamot, A. (2004). Issues in Langauge learning Strategy research and Teaching. Journal of Foreign langauge Teaching, 14-26.

[8] Chamot, A.U., Dale,M., O'Malley, J.M. \& Spanos, G.A. (1992). Learning and Problem Solving Strategies of ESL students. Bilingual Research Journal , 1-34.

[9] Chastain, K. (1988). Developing Second Language Skills: Theory and Practice. Florida: Orlando.

[10] Chimbganda, A. B. (2006). A Study of the Summarization Strategies Used by ESL First Year Science Students at the University of Botswana. Zimbawe: unpublished thesis.

[11] Cohen, A. (2001-05). Preparing teachers for styles- and strategies - based instruction. International conference on langauage teacher education. U.S.: university of Minesota.

[12] Cohen,A \& S. J. Weaver. (1998). Strategies-based Instruction for second language learners. In W. R. Jacobs, Learners and language learning. Anthology Series 39 (pp. 1-25). Singapore: SEAMEO Regional Langauge Centre.

[13] Cohen,A.D \& Weaver,S.L. (2005). Styles and StrategiesBased Instruction: A Teachers' Guide. University of Minnesota: unpublished working papers.

[14] Ellis and Sinclair. (1989). Learning to learn English. CUP: Teachers' Book, P.6-7.

[15] Flower,W.S \& Coe,N. (1976). Nelson English Language Tests. London: Butler and Tanner Ltd.

[16] Graham, S. \& Perin, D. (2007). Writing Next: Effective Strategies to improve writing of adolescents in middle and high school. New york: Carnegie Corporation.

[17] Graham, S. (2005). Teaching writing strategies. San Antonio,TX: Presentation at the McGraw-Hill/SRA Booth at the International Reading Association Conference.

[18] Graham, S.\& Harris, K.R. (2005). Writing Better: Effective Strategies for Teaching students with Learning Difficulties. London: Paul H. Brookes Publishing Co., Inc.

[19] Grenfell, M. a. (1999). Modern Languages ad Learning Strategies:In theory and practice. London: Routledge.

[20] Hadley, A. O. (1993). Teaching Language in Context. Boston: Heinle and Heinle Publishers.

[21] Hosenfeld, C., Arnold, V., Kirchofer, J., Lanciura, J. and Wilson, L. (1981). Second language reading: a curricular sequence for teaching reading strategies. Foreign Language Annals 14 (5) , 415-22.

[22] Idris, N., Baba, S. and Abdullah, R. (2008). Using Huristic Rules from Sentence Decomposition of Experts' Summaries to Detect Students' Summarizing Strategies. International Journal of Human and Social Sciences 2;1 , 28-32.

[23] Jurkovic, V. (2010). Effect of Explict language learning strategy instruction on language-test and self-assessment scores. English language Teaching(CCSE).Vol.3,No.1 , 1627.

[24] Knudson, R. (1998). College students' writing : An assessment of competence. Journal of Educational Research, 92(1) , 13-20.

[25] Kumaravadivelu, B. (2006). Understanding Language Teaching, from Method to Postmethod. Mahwah, New Jersey: Lawrence Erlbaum Associates, Inc.

[26] Lane,K.L , Harris, K.R , Graham,S , Weisenbach, J.L ,Brindle, M \& Morphy, P. (2008). The Effects of SelfRegualted Strategy Development on the Writing Performance of Second-grade students with Behavioral and Writing Difficulties. The Journal of Special Eduaction, Vol.41, No.4, 234-253.

[27] Larsen-Freeman, D. (2000). Techniques and Principles in Language Teaching. Oxford: Oxford University Press.

[28] Lee, Y. (2010). Coping and summarizing: Possible tolls to develop english reading and writing for university students of different proficiency levels in Korea. U.S.A: UMI, Dissertation Publishing. 
[29] Lougheed, L. (2008). Writing for TOEFL iBT. U.S.A: Barron's Educational series, Inc.

[30] McMullen, M. (2009). Using language learning Strategies to improve the writing skills of Saudi EFL students: Will it really work? ScienceDirect , 418-433.

[31] Mousapour Negari, G. (2011). A study on strategy instruction and EFL learners' writing skill. International Journal of English Linguistics, Vol. 1, No. 2, 299-307.

[32] Naiman,N., Frohlich, M., Stern,H.H and Todesco,A. (1996). The Good Langauge Learner. Canada: The Ontorio Institute for Studies in Education.

[33] Nunan, D. (2001). Second Language Teaching and Learning. Boston: Heinle and Heinle Publication.

[34] O'Malley,J.M \& Chamot, A.U. (1990). Learning Strategies in Second Langauge Acquisition. New York: Cambridge University Press.

[35] Oxford, R. (1990). Language Learning Strategies: What every teacher should know. New york: Newbury House Publishers.

[36] Reidle, C. (2011). How to get the most from summarizing strategies? TEXAS SCHOOL IMPROVEMENT CONFERENCE 2011 (pp. 1-5). Texas: unpublished.
[37] Richards,J.C \& Schmidt,R. (2002. Third Edition). Longman Dictionary of Language Teaching And Applied Linguistics. U.K: Pearson Education Limited.

[38] Romero Perez J.F., Bandera E.E., Leon I.R.\& Cervan, R.L. (2003). Application of a written composition and reading comprehension program in primary education students. Electronic Journal of Research in Educational psychology No.1, 57-78.

[39] Rubin, J. (1975). What the " good langauge learner" can teach us. TESOL Quarterly, 41-51.

[40] Stern, H. H. (1992). Issues and Options in Language Teaching. Oxford: Oxford University Press.

[41] Weigle, S. C. (2002). Assessing writing. U.K: Cambridge University Press.

[42] Wenden, A. L. (1991). Metacognitive strategies in L2 Writing. In J. Alatis, Georgetown university Round table on Langauge and Linguistics (pp. 302-322). Washington, D.C: Georgetown University Press.

[43] White, R., \& V. Arndt. (1991). Process Writing. London: Longman. 